\title{
Learning to teach and learn (not only foreign languages) during the coronavirus pandemics
}

\author{
Alena Haskova - Romana Havettova - Zuzana Vogelova
}

DOI: 10.18355/XL.2021.14.01.01

\begin{abstract}
The authors in the article present the main phenomena that during the state of emergency declared by the Government of the Slovak Republic due to the spreading coronavirus pandemic should contribute to managing the situation and support the functioning of the educational environment of primary and secondary schools in Slovakia in the newly established conditions. Following the summarization of the relevant phenomena, findings arising from the acquired experience of teachers from practice are presented. The analysis of the acquired experience was processed on the basis of panel discussions with teachers, which were focused on a critical evaluation of their practical experience in providing education for primary and secondary school students during an emergency and a subsequent emergency situation. At the same time, both the described process of learning to teach and learn under the pandemic situation, as well as the presented findings resulted from the panel discussions, are put in an international context and compared with the situation and experiences from other countries.
\end{abstract}

Key words: regional and local schools (ISCED 1 - ISCED 3), coronavirus pandemic, educational environment, online teaching, remote instruction, challenges, opportunities, teachers`experiences, and opinions

\section{Introduction}

The coronavirus pandemic, within a few months of its outbreak, has dramatically changed the lifestyles of the entire world, with billions of people being forced to stay at home, observe self isolations, and work and learn from home. It has limited the freedom of people to move, trade, or associate. In general, it has caused an unprecedented crisis in all areas, not excluding the education sector.

In the field of education, the corona pandemic has created the most considerable disruption of education systems in history. Governments responded quickly to protect the safety of learners and education actors by closing schools and other educational institutions. According to data from the United Nations Educational, Scientific and Cultural Organization (UNESCO), in order to prevent the spread of the virus and mitigate its impact, by mid-May 2020 nearly 1.6 billion learners in more than 190 countries and all continents had stopped having their face-to-face lessons (ECLACUNESCO, 2020; UN, 2020). In this way, closures of schools and other learning spaces have influenced 94 percent of the world's student population. On the other hand, this crisis has outstandingly stimulated innovation within the education sector, as the sector faced the challenge of transition to online education.

Ensuring learning continuity during the time of school closures became a priority for governments the world over, and many of them - as it is above mentioned - turned to ICT, requiring teachers to move to online delivery of lessons. The use of educational technology platforms became a new reality for all kinds of schools and educational institutions, including both educators and learners. In conditions of isolation, quarantines, and lockdowns, technology became the main means to pupils/studentteacher connection and communication, as well as an essential tool to offer continuous education possibilities. Educational institutions that have integrated the use of 
emerging technologies in their systems before the outbreak of Covid-19 had a comparative advantage over those who were yet to embrace technology in their operations. Teachers were required to teach remotely, and pupils/students needed adjustments to the new teaching and learning techniques (UN, 2020; Di Pietro, Biagi, Costa, Karpinski, Mazza, 2020). This occurred at every level of education), moreover, very often without any relevant guidance, training, or resources. Teachers across the globe were primarily unprepared to support continuity of learning and adapt to new teaching methodologies. Even in contexts with adequate infrastructure and connectivity, many educators lacked the most basic ICT skills in relation to online teaching and learning, and they struggled with their own ongoing development, very often let alone with facilitating distance learning (ECLAC-UNESCO, 2020). The corona pandemic has highlighted that both teacher trainees as well as in-service teachers, need to be trained in new methods of education delivery connected with online forms of education.

On the other hand, some countries integrated psychological support into their contingency plans, manuals, and guides for teachers and local associations, and nongovernmental organization NGO mobilized to provide additional support (ECLACUNESCO, 2020).

In general, the transition to online education posed a challenge to both teachers as well as pupils/students as many of them, on both sides, lacked the needed facilities, digital skills, and expertise to implement remote teaching and learning. Technology represented a means to bridge the gap in the education process maintaining. The increasing use of technology in education had modified teachers' methods from the traditional approach to a new, more flexible approach (Onyema, Deborah, Alsayed, Noorulhasan, Sanober, 2019; Kobylarek, 2019; Pushkarev, Pushkareva, 2018). However, as some of the authors state (Onyema, Eucheria, Obafemi, Sent, Antonye, Sharma, Alsayed, 2020) though, technology can be used to remedy some of the fallouts from school closures; it cannot replace the important effect of face-to-face interactions by pupils/students and teachers. So the transition to online and at-home learning increased pressures on pupils/students, teachers, and parents, too, especially those with limited digital skills, education, and resources for remote education.

\section{Education processes under the pandemic situation in Slovakia}

In Slovakia, as a result of preventive measures against the spreading pandemics, approximately 450000 primary school pupils, 200000 secondary school students, and almost 100000 university students have remained at home since March 16, 2020 (Burgerova, 2020; on the basis of the government resolution of Peter Pelegrini of March 11, 2020, a declaration of a state of emergency in the wake of the new coronavirus pandemics of March 16, 2020.) An emergency situation has arisen, and in practice, it has been shown that the Ministry of Education, Science, Research and, Sport of the Slovak Republic (MSVVaS SR, hereinafter referred to as the Ministry of Education) is not prepared for emergency situations. In the confusing division of competencies between the Ministry of Education, school founders, school management, and teachers, a situation arose in which individual participants mostly waited for the decisions of the others.

Schools tried to gradually start teaching via the Internet. However, apart from the information that they should teach, teachers did not receive any instructions from the Ministry of Education. Both schools and teachers fit the situation as they knew it each school, each teacher according to their facilities and abilities. A positive shift 
came after the appointment of a new government (March 21, 2020 - government coalition of political parties OLaNO, We are a family, SaS, For People under the leadership of Prime Minister Igor Matovic).

The main pillar of the operation of the educational environment of primary and secondary schools during quarantine was the website www.ucimenadialku.sk, which was established by the Ministry of Education in cooperation with several nongovernmental organizations.

The purpose of setting up the website www.ucimenadialku.sk, was the effort of the Ministry of Education to help pedagogical and professional staff, management and founders of schools - as well as pupils/students, and parents -to cope with the situation, to be able to orientate themselves in to find new solutions for the functioning of school educational environments during the interruption of traditional teaching. The schools appreciated the establishment of this site but appreciated, in particular, its subsequent flexible operation, which significantly contributed to streamlining the transmission of information (see the previously mentioned positive shift in information communication after the appointment of the new government). Important deadlines were published on the portal, as far as possible clear guidelines for schools and school facilities, recommendations for school management and teachers on how to proceed at a time when attendance is interrupted while respecting the possibilities and needs of individual pupils/students, parents, and teachers.

An important part of the website www.ucimenadialku.sk, as a pillar of the operation of the educational environment of primary and secondary schools, was its support subpage Podpora and the section \#zvladnemetodoma.

The support sub-page Podpora is primarily intended for teachers in order to exchange experiences with each other. At the same time, however, it also provides space for a wider range of interested parties (individuals, interest groups, educational institutions, various foundations) to implement webinars, make available either own or downloaded video tutorials, or to provide consulting and advisory services.

The website $w w w . z v l a d n e m e t o d o m a . s k$, provides suggestions for activities aimed at all-day care for children with disabilities. This section was created at the time of the coronavirus pandemic as part of the Inklulinka project, implemented jointly by the Platform of Families and the Foundation for Children of Slovakia.

Already on the first day of the launch of the www.ucimenadialku.sk website (March 26 2020), 119602 visitors visited it, and the number of views of each site reached 588678 views. The most visited were online resources that teachers can use to apply distance learning, current changes to deadlines in the organization of the school year, as well as recommendations for online assignments, and advice and tips. At the same time, more than 250 different suggestions and questions were received from parents, teachers, founders, non-profit organizations, and others. The issues were mainly directed to the area of industrial relations and the implementation of online education (Bartosovicova, 2020). More than 100 webinars, online hours, digital learning materials, recommendations for teachers, professional staff, parents, universities, and counseling were provided through the portal.

XLinguae, Volume 14 Issue 1, January 2021, ISSN 1337-8384, eISSN 2453-711X 
The www.ucimenadialku.sk website also includes an overview of available communication tools and platforms, electronic resources, and existing support for schools, pedagogical and professional staff, as well as for parents.

As an additional pillar of the functioning of the educational environment of primary and secondary schools during quarantine can be seen by the Ministry of Education managed the State Educational Institute (under the administration of which the portal www.ucimenadialku.sk also passed). This institution was appointed by the Minister of Education of the Slovak Republic Branislav Gröhling to design further solutions to the successful management of the situation. At the same time, Miroslava Hapalova (MSVVaS, 2020), an educational analyst in the field of inclusion, was entrusted with the management of the State Pedagogical Institute (SPU), replacing the previous director of SPU Ludovit Hajduk.

The first measure to facilitate the current situation for all participants in education was to stop giving grades (from April 6, 2020) in the ongoing assessment of pupils during interrupted school lessons and to recommend to schools that teachers should not take into account grades that were awarded to pupils during the outbreak of the pandemic. The main purpose of this measure was to provide pupils with verbal feedback in particular and to motivate them to learn. As part of the final evaluation, schools were allowed to evaluate pupils in all grades verbally. Schools were, therefore, able to choose whether to classify pupils, i.e. to rate their grades, or whether to rate them verbally or by combining both types of assessments. The exception were pupils in the first years of primary school, for whom verbal evaluation was ordered as a mandatory (only) way of the final assessment of pupils.

Another measure was the recommendation not to classify pupils within subjects in which it was not possible to meet the objectives of the subject at the time of interrupting teaching in schools. In these cases, the school stated on the student's certificate that the student had completed the subject. It was also not recommended to evaluate pupils/students (both primary and secondary schools) on the basis of tests and written examinations, the obligation to carry out the prescribed written tests was abolished, and students could not be given insufficient final evaluation. On the basis of the decision of the Minister of Education Branislav Gröhling, testing of ninth graders, entrance examinations for secondary schools, and oral part of the final secondary school examination were canceled (the ninth graders were accepted to the secondary schools following their results achieved in 8th and 9th grades, and those students who did not accept the granting of the fina exam evaluation according to the average of their marks could have asked for passing the oral part of the final exam).

For teachers and parents who had questions about the Ministry of Education in connection with measures against the spread of coronavirus, the Ministry of Education has set up a free infoline Advisory Call Centre of the Ministry of Education (Poradenské call centrum MSVVaS SR). Within the advisory center, the information was provided both by telephone and on the basis of an email contact helpdesk@iedu.sk.

A similar email and telephone counseling service were set up by the Research Institute of Child Psychology and Patopsychology (Vyskumny ustav detskej psychologie a patopsychologie VUDPaP). In particular, it was advice on how to work at home during quarantine with children with special educational needs and disabled children. 


\section{Analysis of the functioning of the educational environment in pandemic conditions}

While the role of these pillars and support services was to create or facilitate the creation of an appropriate educational environment to ensure the implementation of primary and secondary school pupils'/students' education during the coronavirus pandemic, the main burden stayed nevertheless on teachers. Each school and every teacher dealt with this situation depending on their possibilities and abilities.

Analysts at the Institute for Educational Policy (IVP) warned back in April that a significant proportion of pupils/students had been excluded from education as a result of the introduction of a distance form of teaching for primary and secondary school pupils. According to their estimates, ten thousand children were unable or could not participate in home online teaching (estimated total number of 32000 pupils without internet access), especially children from socially disadvantaged backgrounds (Bednarik, Cokyna, Ostertagova, Rehus, 2020).

Despite the warnings given by analysts of the Institute of Education Policy, the situation in practice was not so dramatic thanks to the approach of teachers to the situation and the specific conditions of their school and pupils. The main burden of ensuring a proper educational environment of distance teaching for their pupils was carried out by teachers. Those teachers who could use the distance form of online teaching had to deal with the burden of creating teaching materials (content) for this form of education. Those teachers who were unable to use the distance form of online teaching had to deal with the burden of creating and delivering written assignments and materials (especially in the case of rural school teachers personally handing out teaching materials created by them and assigning projects or duties to mailboxes).

In an online survey carried out by Focus for Dennik $N$ (Gdovinova, 2020), parents of primary school pupils were asked to comment on the provision of distance education for students by the school their child attends. As many as $76 \%$ of parents who took part in the survey assessed the way and level of how their child's school reflected the interruption of teaching and the provision of further education for pupils positively. At the same time, $62 \%$ of parents in demand declared that teachers only outsourced homework to pupils via the Internet (e.g., via EduPage), but online teaching did not take place. $19 \%$ of parents who participated in the survey said that the teachers were doing interactive teaching via the Internet, including entering activities, and $12 \%$ said that the teachers read the new material to the monitor and then commission homework (e.g., via EduPage). $58 \%$ of parents confirmed daily communication between teachers and students.

The results of the Dionysus Ilkovic Foundation survey (Dionysus Ilkovic Foundation/ Nadacia Dionyza Ilkovica, 2020) point to the heavyweight of burden that had to be taken by teachers who implemented distance learning for pupils/students in the form of online teaching. The survey focused on the experience of teaching during the pandemic and interviewed 570 science and technology teachers from primary and secondary schools. The results of the survey make it clear that teachers were essentially self-reliant, despite the established support pillars for the online learning environment. As many as $77 \%$ of teachers used their own techniques to handle the situation, and as many as $90 \%$ of teachers also created their own content. The created teaching materials were subsequently provided by each other to each other. Only less than a quarter of respondents used teaching materials provided by the Ministry of

XLinguae, Volume 14 Issue 1, January 2021, ISSN 1337-8384, eISSN 2453-711X 
Education. At the same time, as stated by the teachers themselves (or as the $90 \%$ of teachers who also created the content of teaching themselves), the preparation of teaching materials for online education is much more demanding than the preparation of materials for regular teaching at school. For this reason, the teachers in demand agreed that coping with the whole situation would make it easier for them to have available content to work within online educational environments. EduPage and Zoom, MS Teams, and Skype teleconferencing tools have been identified as the most commonly used tools in online educational environments.

At this point, we consider that it is necessary to highlight the problem of undergraduate training of future teachers and further training of teachers from practice in shaping their didactic and technological competencies or developing their professional digital literacy. In the Czech Republic and Slovakia, the focus of undergraduate teacher training in the field of shaping their didactic-technological competencies is aimed at developing the ability of teachers to use various software applications in their pedagogical work or to create multiple teaching materials and teaching aids in these applications. The rapid development of either new or upgraded versions of software applications is linked to the need for continuous innovation of the part of the teaching curricula focused on didactic-technological competencies and their digital literacy. In the period 2017-2019, extensive research investigators were carried out within the Slovak and Czech provenance, the aim of which was to create a platform for the design of an optimal model of undergraduate teacher training in didactic-technological competencies, with an emphasis on shaping their professional digital literacy. However, the final design of the optimal model (Zahorec, Haskova, Munk, 2020) is based on the situation before the pandemic. During the pandemic, it became clear that it may be more important for teachers to be prepared to use online teaching systems than to be ready to use different software products in the teaching of individual subjects. In assessing how online education took place during a pandemic, it should be borne in mind that most teachers have not encountered online teaching until then, and no one has ever taught them how to teach in this form. The fact that teachers finally mastered this form of teaching during the pandemic is mainly due to their personal commitment and ingenuity. According to teachers (Nadácia Dionýza Ilkoviča, 2020), in order to be able to fully educate students via computer (online), they need to have adequate technical equipment, acquire appropriate computer skills, and in addition need special content and enough time for preparation. According to teachers $(90 \%)$, it would be good for teaching online education and working with relevant systems to be included in undergraduate teacher training at faculties of education.

\section{Research survey aimed at evaluating the experience that was gained}

Due to the coronavirus pandemic, it was necessary to change the operation of the educational environment of primary and secondary schools. In the previous part, measures (pillars) put into practice in an effort to create an appropriate support apparatus for the operation of the educational environment of primary and secondary schools in conditions of the spreading pandemic are analyzed. In order to evaluate the experience that teachers gained during the performance of their pedagogical activities in these new conditions, two-panel discussions were held - one in the environment of a primary school and one in the environment of a secondary school in the Nitra region. In terms of content, both discussions focused on the presentation of experiences and the exchange of teachers opinions on four fundamental issues:

1. How did the school cope with the provision of teaching (education) of pupils in the newly occurred conditions of the pandemic? 
2. How did the teachers react to this situation? How did they assign tasks to students?

3. How did the students react to this situation? How did they get involved in teaching, how did they perform the assigned tasks?

4. How did the pupils' parents react to this situation? Did they communicate with the school, were they helpful, did they support the school's efforts?

In both cases, the function of the moderator was held by a teacher working at the relevant school.

During the processing of the records of the research investigations in the first phase, the findings from each panel discussion were analyzed separately and then summarized in the overall, general conclusions resulting from both discussions.

The conclusions of the discussion of teachers' experiences can be summarized in the following points:

- Teachers responded to the situation promptly and, according to the content of the subject, chose an acceptable form of teaching.

- During the last personal contact with teachers, students were given assignments for the next one to two weeks.

- $\quad$ Some subjects were taught online via Zoom.

- The problems were initially of a technical nature - the availability of computers for teachers and for teachers to adopt new programs and start using them. Due to the fact that both schools already in the previous school year used the EduPage platform to keep an electronic class book, or to communicate with students and parents, in the case of the secondary school also to send various teaching materials to students and chats between staff, these problems were handled correctly promptly.

- A much more serious problem was the technical equipment of pupils and students, especially those from socially disadvantaged backgrounds (computer security, the need to share a computer with siblings but also parents who also worked online, the problem with WIFI, insufficient prepaid data, etc.). In many cases, teachers generally encountered pupils/students' reluctance, unwillingness to cooperate, even when there were no objective reasons.

- A serious problem on the part of students was also the level of their digital literacy (even in the case of the secondary school students - insufficient computer skills, they can not download documents, they can not find information in the virtual world, the necessary websites). In addition, there are pupils/students who, without objective reasons, are not interested and ignore such organized teaching (education).

- In the first phase of distance teaching, an oversized volume of tasks was assigned (both in the case of primary and secondary school, oversizing occurred in terms of quantity but also complexity, with frequent occurrence of formulations with which pupils/students had problems). Based on this fact, teachers subsequently reduced the demands placed on pupils/students, assigned smaller volumes of tasks and less demanding activities that all pupils/students could handle. And, of course, as needed, they modified the way they used to 
create appropriate texts for the learners so that they could understand them and the texts would not be too long for them.

- In connection with the introduction of online education systems in teaching as well as the creation of teaching materials for distance education of the learners (pupils/learners), teachers learned both themselves and, in particular, they learned from each other.

- All teachers have been involved in online education. And they all identically and unambiguously mark the assignment of tasks, their correction, evaluation and subsequently informing pupils and students not only about evaluation but also about mistakes (incorrect solutions) as more time-consuming in comparison with the classical form of teaching. Online teaching lacks direct contact with pupils/students; it is more difficult for them to explain something they did not understand; there is no possibility to promptly explain it and show it clearly. Nothing replaces direct work in class. In addition, online teaching brings additional burdens and stress to teachers, as they have to encourage nonworking pupils/students by email, Facebook message, or telephone to work. Many students ignore this and do not respond to repeated challenges.

- Assignments for all tasks, including video links, interactive exercises, and other activities, were published for the secondary school students on the school's homepage.

- $\quad$ The feedback from students was diverse. There are students who have started working together automatically, some have apologized for having a weak internet connection, but some students have been left without any feedback.

- Students who achieved excellent to good results during their previous studies (classical school teaching) cooperated with teachers regularly and sent them elaborated exercises for control (email, WhatsApp, Messenger).

- Students with only satisfactory results cooperated irregularly or even without showing any feedback.

- Students were led to independence and time management, as they always had to send the completed assignments by the deadline. For some, this form suited, because they knew how to divide the time according to their biorhythm and the extent of their school, respectively and other domestic duties. However, it definitely did not suit everyone, or there was also "abuse of the situation ".

- The classification of students was a big problem. Teachers pointed out the low level of objectivity of the distance study classification, as other factors and persons searching from various sources also entering the educational process, and it is not guaranteed what knowledge the student has acquired or whether the submitted assignments are actually the result of his/her work. Teachers consider the distance form of study to be a type of activity during which the student acquires knowledge, but with a low degree of verifiability.

- Teachers positively assessed the initiative help offered to schools by Oxford Publishing - providing until August 31, 2020, the opportunity to use all online activities (online textbooks, exercise books, simplified novels at various levels, etc.) free of charge through the publisher's homepage.

- Communication with pupils' parents was carried out mainly through telephone connection and email. Parents were encouraged to supervise their children and to support and control them in the implemented methods of distance education. 
Providing this communication was very time consuming, especially for class teachers.

- Many parents, especially those who had to go to work, contacted teachers both to check that their children were taking part in individual activities and to the tasks assigned to them, and to justify their children who were alone at home and did not know to connect to online lessons (or have experienced some technical issues with the computer or the connection itself).

- In the case of most comments from parents, these have been solved continuously (e.g., requests for more time, for various reasons, for the elaboration of some assignments). No negative comments were received. However, just as there were cases of non-involvement of pupils in the implemented educational processes, so also in the case of parents, there were cases of absolute lack of interest in any cooperation and contact with the school.

- $\quad$ Parents often did not manage the long-term stay of children at home; they stressed themselves and their children; in some cases, they fought with teachers. On the other hand, many parents began to pay more attention to their children, and many began to accept the work of teachers, understood that learning is not easy, and changed their negative attitudes towards school and learning into positive ones.

- $\quad$ In some, not very rare cases, parents did tasks instead of children.

- An interesting phenomenon was "the permanent observation "of parents of the carried out online process of their children teaching, with whom the teachers were confronted (e.g., parents "needed to wipe the dust "in the room where their child was attending online teaching).

- Many parents also started writing to teachers privately and began to consult with them on private matters.

To illustrate, we present several examples of interesting experiences presented by teachers during the panel discussions:

- In the first days, each teacher went according to how s/he imagined distance learning. Some started learning to learn online, some only taught by assigning tasks to students. We didn't track the amount of the tasks we sent, and that came back to us - when the children started sending back the solved tasks, and we did not have time to check and reply to their emails. In this, we, the online teachers, had a great advantage because we taught the children via Zoom, so we did not necessarily need many tasks.

- Teachers spent a lot of time checking, correcting work and assignments, feedback to students, and especially verbal assessment. It should not be forgotten that teachers are also in charge of 150-300 students.

- Many of us have had to deal with the question of whether we are teachers or parents at home. Especially we with small children had a problem explaining to our children that the mother is at home but working. After two months of quarantine, we have already taught our children that during online lessons, they could not run into our room, but if they want to see us, they just peek and wave.

- $\quad$ The children were so excited about the new way of teaching that the parents asked us to teach like this over the weekend, which of course, we refused.

XLinguae, Volume 14 Issue 1, January 2021, ISSN 1337-8384, eISSN 2453-711X 
- It was a beautiful chance for the children, they saw each other and heard, and that was the reason why the first month went with enthusiasm. Learning online is very interesting and creative. But it's very difficult to prepare because keeping children's attention is really a masterpiece. We had to constantly invent new things. And yet, for the second month, enthusiasm waned, and it became increasingly difficult to keep the children's interest.

- $\quad$ The most beautiful reward for all my efforts was when during the online lessons, the mother of one of my students came to the camera and asked me for my email and phone number because her son wants to nominate me as the best teacher.

The above-mentioned conclusions of the discussions with the teachers also confirm the comments of the students themselves, who were subsequently asked to comment on the course of teaching activities organized by the school during the declared emergency situation of the spreading pandemic. As an example, here are at least some of them:

- I think it was handled well. For my school, I think the teachers were quite considerate with students who did not send homework on time. Something was difficult to understand, but it was nothing that could not be resolved with a teacher or consulted with classmates. And as for the other schools I've heard somewhere, I didn't like the fact that the students had too many assignments and tests. By that, I mean three tests in one day or only one day to write larger notes. Of course, it's manageable; I'm not saying no. I just didn't like it.

- I probably take it as a positive that we had more time to work out tasks than at school. And the positive thing is that I had less stress than when I went to school every day. I take it as negative that when we had some tasks that were more difficult, or I didn't understand them, then no one was there to explain it to me as when I was in school.

- It was demanding from the point of view that everything had to be photographed and then sent. And we didn't have as much communication as at school with the teachers. Or, for example, it was difficult to practice. We don't have such technical equipment at home as at school for practice. And marking is also more complicated.

- $\quad$ Even though I missed school, I liked this form of learning, as I had more time and I could share when I learn.

- $\quad$ The only disadvantage of learning via the Internet is that I do not understand the new theme as the professor explains it to us in class.

- $\quad$ This teaching is much worse for me than at school. It can all be done well, but we need to pay more attention to it. The good thing, in my opinion, was that I did everything in the comfort of my home and I had more time to think.

- $\quad$ I didn't like that the teachers sent us two times more than when we go to school normally. I didn't have time for anything but doing homework.

- I did not understand many things because we did not take them over, and when I do not hear the interpretation of the curriculum, it is more difficult to understand it.

- $\quad$ The nice thing was that I didn't have to get up at 6 o'clock in the morning. I could help myself on the Internet; I had more time to do homework. 
- What I didn't like: some students could cheat a lot, sometimes we weren't sent homework assignments, and we had to ask them from professors, we couldn't take new themes that needed to be explained to us, and of course, I missed my classmates and school environment.

\section{Conclusion - pros and cons of online education}

Nowadays, most aspects of education are going digital, and education stakeholders, including teachers and students, are confronted with the challenge of transition to online education. The coronavirus outbreak has forced millions of students to study and learn from home. This is not a new phenomenon because the home has long been the epicenter of learning, particularly as regards informal education). Currently, learning from home is becoming a new norm for students. The majority of university students prefer to study in the comfort of their own homes because the learners tend to have everything at their disposal without having to leave their chairs (Onyema, Eucheria, Obafemi, Sent, Antonye, Sharma, Alsayed, 2020). But the success of online education depends on a lot of factors, including available and accessible technical infrastructure, good internet connections, learning software, digital instructional materials, digital skills of teachers and students.

Currently, an outstanding broad scaled research, topically to which in some topical features the above presented our research survey has been similar, has been carried out in Finland. The research is funded by the Ministry of Education and Culture, and its implementors are the Finnish National Agency for Education Services, the Research Group for Education, Assessment and the Learning and Research Group on Children and Adolescents' Health Promotion of Tampere University, and the Centre for Educational Assessment at the University of Helsinki. Its aim is to analyze the effects of Covid-19 in Finish schools, how the pandemic situation has affected children's education, the work of all those involved in school-related activities, and the well-being of families. The purpose of the study is to provide an overall picture of the impact of exceptional circumstances on school operation (e.g., how teachers' work has been supported by principals and other teachers, what kind of lessons for the future can be learned, variety of assessment practices used during the exceptional situation) and to collect information in preparation for the next school year. Research data have been collected from all Finish basic education school principals and teachers and other staff of the schools (people working with students in the schools), and students (of 4th to 10th grade) and their parents or guardians. The research has started in May 2020 and will continue during the 2020/2021 school year. As the first results of the Finish nationwide study show, despite the fast transition period to online forms of education, distance learning in Finland went technically surprisingly well. To compare with Slovakia, the technical infrastructure of schools in Finland is on a higher level, but similarly to Slovakia, digital devices used for learning (in Finland, e.g., personal laptops) varied from school to school (in Slovakia, this is more a question of the lack of the digital devices which the schools have at their disposal). In Finland, this situation was solved mostly by arrangements that required more work and financial resources from families. A lot of students reported that distance learning had suited them well, and they felt that learning at home had been more effective than at school. However, nearly half of 7th to 9th-grade students and a third of elementary school pupils reported that they had learned less than usually during distance learning (Ahonen, 2020). So the conclusion resulting from the first findings in Finland is that if distance learning is realized again, the focus should be on the content of learning and supporting students.

XLinguae, Volume 14 Issue 1, January 2021, ISSN 1337-8384, eISSN 2453-711X 
Of course, in general, it is clear that teachers and students have to be better prepared and supported if teaching and learning are to be carried out in online forms, beyond classrooms, and this training and support should be guaranteed. But as it is stated in United Nations Policy Brief (UN, 2020), technology alone, or even technology together with digital skills, cannot guarantee good learning outcomes. More important than training teachers in ICT skills is ensuring that they have the assessment and pedagogical skills to meet students at their level and to implement the accelerated curricula and differentiated learning strategies likely to emerge in return to school. Digital solutions need relevant content, adequate instructional models, effective teaching practices, and a supportive learning environment. The development and professionalization of teachers are key to ensure they are sufficiently qualified, remunerated, and prepared. Governments could also strengthen systems of support for teachers, facilitators, and parents/caregivers in the successful and safe use of technology for learning (UN, 2020). Quality education cannot be provided through content built outside of the pedagogical space and outside of human relationships between teachers and pupils/students. Technology can be used to remedy some of the fallouts from school closures, but it cannot replace the important effect of face-to-face interactions by pupils/students and teachers.

Moreover, as it is also seen from the above-presented results of our research survey, the school closure due to coronavirus has to point out (besides the basic problems related to the availability of the needed technologies and students and teachers' basic digital skills) a lot of problems which have to be taken into consideration in regard to the transition to online teaching and at-home learning. There have to be taken into consideration (also) increased pressures on teachers, pupils/students and their parents, especially those with limited digital skills, education, and resources for continued education, as to parents also increased demands to perform supervision tasks of ensuring that their children learn from home, increased probability of dropouts due to loss of interest in education and lack of resources to continue, and last but not least also a possibility of a negative impact on the occurrence of sociopathological phenomena (e.g., possible increase of the rate of youth involvement in crimes due to prolonged school closures). In this context also Di Pietro et al. (2020) point out that some European countries consistently indicate that, on average, students may suffer a learning loss and that the transition to remote instructions may influence both cognitive and non-cognitive skills acquisition negatively and may have important long-term consequences (in addition to the short-term ones). Di Pietro et al. give this in connection with three main aspects of the transition. The first one is that quarantined students tend to spend less time learning compared to when schools are open. The second one is that many students confined at home due to Covid-19 may feel stressed and anxious, and this may negatively affect their ability to concentrate on schoolwork. And the third one is the fact that school closure and the lack of in-person contact may make students less externally motivated to engage in learning activities.

Influenced by the same circumstances, due to preventive measures against the spread of Covid-19, practices from different countries promoting the transition of education to remote instructions are essentially the same. The success of these practices in particular environments depends, on the one hand, on the level of available technical infrastructure and digital skills of the concerned subjects, but on the other hand, there is a lot of factors even more important to achieve relevant results. Students should be given, also in online forms of education, the opportunity to master the subject materials in different forms, provision to access teaching materials in a variety of ways, a serious problem represent an assessment of students or support given to teachers to manage the increased load of work related to the preparation of this kind of teaching. 
Finally, online learning has not only brought many complications, but the pupils/ students have also learned digital skills they did not know before, tolerance, teamwork, and cooperative learning. They learned to work independently; they were able to take responsibility for the tasks that teachers sent them. Students have proven that they are capable of autonomous learning and can work with a variety of resources. Teachers, on the other hand, have found that online space is not an easy challenge for every teacher. They have learned that family-school cooperation must be at the forefront of education. An interesting finding was that students with developmental learning disabilities performed better than at school. We explain this by a pleasant family environment, which did not add unnecessary stress. No monitor can replace the personal contact with students. Students and their smiles, jokes, but also their conversations with teachers; are the moments that are missing during online learning. But as teachers have to be able and to continue to teach online (also because of the second wave of the corona pandemic), they have to learn new methods related to online forms of education and to bring new ideas on a daily basis that are necessary to master the teaching process. That is why we clearly need to bring online learning know-how to universities and faculties of education for future teachers, who will be soon responsible for future generations.

\section{Bibliographic references}

AHONEN, J. 2020. Researchers investigate the impact of the Covid-19 exceptional circumstances on schooling and student well-being in Finland. In: ENIRDELM Newsletters, pp. 18-20.

BARTOSOVICOVA, M. 2020. Korona virus meni skolstvo. K uceniu online pribudne slovne hodnotenie. Available online: https://vedanadosah.cvtisr.sk/koronavirus-meni-skolstvo-k-uceniu-online-pribudneslovne-hodnotenie.

BEDNARIK, M. - COKYNA, J. - OSTERTAGOVA, A. - REHUS, M. 2020. Ako $\mathrm{v}$ case krizy zabezpecit pristup k vzdelavaniu pre vsetky deti. Available online: https://www.minedu.sk/data/att/16113.pdf.

BURGEROVA, D. 2020. Sumar udalosti: Koronavirus a co sa v skolstve stalo po nom. Available online: https://www.ktochyba.sk/sumar-udalosti-koronavirusskolstvo-v-skratke.

DI PIETRO, G. - BIAGI, F. - COSTA, P. - KARPINSKI, Z. - MAZZA, J. 2020. JRC technical report: The likely impact of COVID-19 on education: Reflections based on the existing literature and recent international databases. Luxembourg: Publications Office of the European Union. ISBN 978-92-76-19937-3. DOI: 10.2760/126686

ECLAC-UNESCO. 2020. Education in the time of COVID-19. In: COVID-19 Report. Available online: https://www.cepal.org/en/publications/45905-education-time-covid19

GDOVINOVA, D. 2020. Rodicia su z ucenia s detmi coraz castejsie vystresovani, ulohy pipaju aj o polnoci (+ prieskum). Available online: https://dennikn.sk/1829246/rodicia-su-z-ucenia-s-detmi-coraz-castejsie-vystresovaniulohy-pipaju-aj-o-polnoci/.

KOBYLAREK, A. 2019. Education in the post-scientific culture. In: Journal of Education culture and Society, vol. 10, n. 1, pp. 5-13.

MSVVaS SR. 2020. Statny pedagogicky ustav povedie Miroslava Hapalova. Available online: https://www.minedu.sk/statny-pedagogicky-ustav-povediemiroslava-hapalova/.

NADACIA DIONYZA ILKOVICA. 2020. Ucitelia online vyuku zvladli, no museli si pomoct, ako vedeli - vychadza z prieskumu pocas pandemie Covid 19. Available

XLinguae, Volume 14 Issue 1, January 2021, ISSN 1337-8384, eISSN 2453-711X 
online: https://www.nadaciadi.sk/lepsie-skolstvo/ucitelia-online-vyuku-zvladli-nomuseli-si-pomoct-ako-vedeli-vychadza-z-prieskumu-pocas-pandemie-covid-19/.

ONYEMA, E. M. - DEBORAH, E. C. - ALSAYED, A. O. - NOORULHASAN, Q. - SANOBER, S. 2019. Online Discussion Forum as a Tool for Interactive Learning and Communication. In: International Journal of Recent Technology and Engineering, Vol. 8, n. 4, pp. 4852-4859. https://doi.org/10.35940/ijrte.d8062.118419.

ONYEMA, E. M. - EUCHERIA, N. CH. - OBAFEMI, F. A. - SEN, S. ANTONYE, F. G. - SHARMA, A. - ALSAYED, A. O. 2020. Impact of Coronavirus Pandemic on Education. In: Journal of Education and Practice, Vol. 11, n. 13, pp. 108-121. ISSN 2222-1735.

PUSHKAREV, Y. V. - PUSHKAREVA, E. A. 2018. Philosophical interpretation of knowledge and information: Knowledge value and information diversity in modern communication. In: XLinguae, Vol. 11, n. 3, pp. 176-184.

SAMAD, I. A. - FITRIANI, S.S. - PATAK, A.A. - WEDA, S. 2019. Students' perspective on genre approach in the 'neglected communicative event': Script defense examination in English department. In: Asian EFL Journal, vol. 21, no. 2.2, pp. 3148.

UN (UNITED NATIONS). 2020. Policy Brief: Education during COVID-19 and beyond. Available online: https://www.un.org/development/desa/dspd/wpcontent/uploads/sites/22/2020/08/sg_policy_brief_covid-

19_and_education_august_2020.pdf.

ZAHOREC, J. - HASKOVA, A. - MUNK, M. 2020. Digitalna gramotnost ucitelov v kontexte ich profesijnej pripravy. Bratislava: Univerzita Komenskeho.

Words: 7403

Characters: 48219 (28,80 standard pages)

Prof. PaedDr. Alena Hašková, CSc.

Department of Technology and Information Technologies

Faculty of Education

Constantine the Philosopher University in Nitra

Dražovská cesta 4, 94974 Nitra

Slovakia

ahaskova@ukf.sk

PhDr. Romana Havettová

Mgr. Zuzana Vogelová

Department of English and American Studies

Faculty of Arts

Constantine the Philosopher University in Nitra

Štefánikova 67, 94974 Nitra, Slovakia

Stredná odborná škola obchodu a služieb

Ul. SNP 5, 95301 Zlaté Moravce

Základná škola, Topol'ová 8, 94901 Nitra

rhavettova@yahoo.com

vogelovazuzana14@gmail.com 